Ulrike Waje-Andreassen (f. 1962) er 1. amanuensis og overlege ved Senter for nevrovaskulære sykdommer, Nevrologisk avdeling, Haukeland universitetssykehus.

Ingen oppgitte interessekonflikter
Litteratur

1. Nylenna M. Samvalg - kun et par minutter ekstra. Dagens medisin 2014 ; 7.5 .2014

2. Frøyshov H, Indredavik B, Wyller TB. Indremedisineren, en aktiv bidragsyter i slagbehandlingen. Indremedisineren 2011; 4: 11-3.

\section{Re: Hva er god behandling ved akutt hjerneslag?}

Hjernens fysiologi innebærer en ekstrem sårbarhet for sirkulasjonssvikt, og gjør dermed behandling av hjerneslag til akuttmedisin av fremste klasse. Det eneste målet $\mathrm{i}$ akuttfasen er å begrense hjerneskaden. I sin lederartikkel om god behandling av hjerneslag vektlegger Hanne M. Frøyshov slagenheten med tverrfaglig tilnærming og rehabilitering (1). Hun er nokså skeptisk til «overdreven» trombolytisk behandling. Som vaskulære nevrologer mener vi at Frøyshov i for liten grad forholder seg til moderne kunnskap om hjernens fysiologi. Altfor mange hjerneslagpasienter blir i dag liggende å vente i et akuttmottak mens hjerneceller gradvis dør. Hjerneslagpasienten krever umiddelbar nevrologisk undersøkelse, CT og/eller MR av hjernen og, dersom indikasjon er til stede, trombolytisk og/eller endovaskulær behandling ved et spesialisert sykehus. Det terapeutiske tidsvinduet for intravenøs trombolyse ble først anslått til 3 timer. Senere undersøkelser tydet på at man kunne gi trombolytisk behandling opptil 4,5 timer, men dette er senere trukket i tvil (2).

Det siste halve året har verdens hjerneslagmiljø sydet av entusiasme etter hvert som den ene positive endovaskulære studien etter den andre er publisert. Resultatene innebærer at det må foretas betydelige organisatoriske endringer (3), noe lederartikkelen dessverre ikke diskuterer.

Av ulike årsaker vil ikke alle hjerneslagrammete kunne tilbys reperfusjonsbehandling. Pasientseleksjonen til ulike behandlingsformer krever høy kompetanse innen både prehospital medisin, nevrologi og nevroradiologi. I følge European Stroke Organisations anbefalinger for slagenheter er overvåkning og optimalisering av hjernens perfusjon vel så viktig som tverrfaglighet (4). Frøyshov skriver at opptreningen skal starte så tidlig som mulig. Dette kan være en sannhet med modifikasjoner. Resultatene fra en fersk studie viser at det kan gå dårligere med pasienter som mobiliseres tidlig (innen 24 timer), enn i den subakutte fasen (24-48 timer) (5). Slagenhetens fortreffelighet er for lengst dokumentert, men vi må vokte oss vel slik at fagfeltet får lov til å utvikle seg videre i tråd med kunnskapsomfanget.

Frøyshov konkluderer med at fremtidens slagleger må håndtere blålys og teknologi. For oss vaskulære nevrologer har dette vært en del av hverdagen de siste ti årene. Fremtidens slagleger må ha inngående kunnskap innen nevrologi og nevroradiologi, og et høyt pasientvolum for å kunne individualisere behandlingen slik at mest mulig av hjernen kan bevares.

\section{Mirza Jusufovic}

mirza.jusufovic@medisin.uio.no

Mirza Jusufovic (f. 1980) er lege og stipendiat ved Nevrologisk avdeling, Klinikk for kirurgi og nevrofag, Oslo universitetssykehus. Ingen oppgitte interessekonflikter. Medforfattere: Else Charlotte Sandset, Anne Hege Aamodt, Bjørnar Hassel, Sigrun Kierulf Brækken, Mona Skjelland, Christian Georg Lund

\section{Litteratur}

1. Frøyshov HM. Hva er god behandling ved akutt hjerneslag? Tidsskr Nor Lege foren 2015: 135: 625

2. Alper BS, Malone-Moses M, McLellan JS et al. Thrombolysis in acute ischaemic stroke: time for a rethink? BMJ 2015; 350: h1075

3. Furlan AJ. Endovascular Therapy for Stroke - It's about Time. N Engl J Med 2015.

4. Ringelstein EB, Chamorro A, Kaste M et al: ESO Stroke Unit Certification Committee. European Stroke Organisation recommendations to establish a stroke unit and stroke center. Stroke 2013; 44: 828-40.

5. AVERT Trial Collaboration group. Efficacy and safety of very early mobilisation within $24 \mathrm{~h}$ of stroke onset (AVERT): a randomised controlled trial. Lancet 2015.
Hanne Frøyshov (f. 1967) er overlege ved medisinsk avdeling UNN-Harstad

Ingen oppgitte interessekonflikter. 